\title{
Epidemiological study concerning the extent of Korkhaus area damage in a sample of patients treated in a specialized universitary department
}

\author{
Studiu epidemiologic privind gradul de afectare a zonei Korkhaus la \\ un lot de pacienţi trataţi într-o clinică universitară de specialitate
}
Mihaela Tănase ${ }^{1}$, Daciana Zmarandache ${ }^{1}$, Ioana Stanciu ${ }^{1}$, Aneta Munteanu', Daniela Gabriela Bălan²

${ }^{1}$ Disciplina de Pedodonţie, Universitatea de Medicină şi Farmacie „Carol Davila“, Bucureşti, România

2Disciplina de Fiziologie, Universitatea de Medicină şi Farmacie „Carol Davila“, Bucureşti, România

\begin{abstract}
The aim of the study was to asses the primary teeth integrity from the Korkhaus zone in a sample of patients aged between 6 and 9 years old (72-108 months, mean age 88.43), attending the Paedodontics Department from Carol Davila University, Bucharest.

Material and methods. The retrospective study was conducted on 140 patients (70 girls). Dental status of the Korkhaus teeth was evaluated: sound, decayed, filled, physiological rizalise and early extraction. The carious experience indices were also calculated for each sex: dmft, dmfs, DMFT, DMFS. Data were analysed using Microsoft Excel 2010 software.

Results. Korkhaus zone. Sounds (58.81\%): c- 28.21\%; m1-15.11\%; m2-15.48\%. Decayed (34.23\%): c-3.33\%; m1- 15\%; m2-16\%. Filled (2.26\%): c-0\%; m1-1.07\%; m2- 1.2\%. Physiological rizalise (2.32\%): c-0.65\%; $\mathrm{m} 1-1.37 \% ; \mathrm{m} 2-0.3 \%$. Early extraction $(2.38 \%)$ : c-1\%; $\mathrm{m} 1-0.77 \% ; \mathrm{m} 2-0.5 \%$.

Carious experience. Girls: dmft 5.28 \pm 3.72 ; dmfs 11.62 \pm 10.64 ; DMFT 0.9 \pm 1.49 ; DMFS 1.07 \pm 1.76 . Boys: dmft 4.98 \pm 3.92 ; dmfs 11.49 \pm 12.82 ; DMFT $0.67 \pm 1.13$; DMFS $0.74 \pm 1.3$.

Conclusions. Only $60 \%$ from the Korkhaus teeth were sound. Girls were more affected by caries than boys. Immediate preventive local methods and the treatment of incipient carious lesions are important goals for the primary teeth from the Korkhaus zone.
\end{abstract}

Keywords: Korkhaus zone, carious experience

\section{REZUMAT}

Scopul studiului a fost evaluarea integrităţii dinţilor temporari care alcătuiesc zona Korkhaus la un lot de pacienţi cu vârsta cuprinsă între 6 şi 9 ani (72-108 luni, vârsta medie 88,43 luni), care au beneficiat de tratament stomatologic în cadrul Clinicii de Pedodonţie a Facultăţii de Medicină Dentară UMF „Carol Davila“, Bucureşti. Material şi metodă. Studiu retrospectiv efectuat pe 140 de pacienţi (70 fete). S-a evaluat statusul odontal al dinţilor din zona Korkhaus: integri, cariaţi, obturaţi, cu rizaliză fiziologică şi extraşi precoce. Totodată, s-au calculat şi indicii experienţei carioase pentru întreaga dentiţie: dmft, dmfs, DMFT, DMFS separat pentru fiecare sex. Rezultate. Zona Korkhaus. Integri (58,81\%): c- 28,21\%; m1-15,11\%; m2-15,48\%. Cariaţi (34,23\%): c-3,33\%; m1- 15\%; m2-16\%. Obturaţi (2,26\%): c-0\%; m1-1,07\%; m2- 1,2\%. Rizaliză fiziologică (2,32\%): c-0,65\%; $\mathrm{m} 1-1,37 \%$; m2-0,3\%. Extraşi precoce (2,38\%): c-1\%; m1-0,77\%; m2-0,5\%.

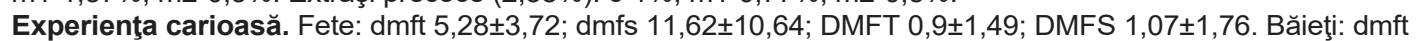

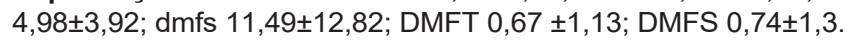

Concluzii. Numai $60 \%$ dintre dinţii din zona Korkhaus au fost indemni. Fetele au fost mai afectate de carie decât băieţii. Se impun instituirea unor metode de profilaxie şi tratarea leziunilor carioase incipiente la nivelul dinţilor temporari din zona de sprijin.

Cuvinte cheie: zona de sprijin Korkhaus, experienţă carioasă

Corresponding author:

Asist. Univ. Dr. Daciana Zmarandache

E-mail: prelipceandaciana@yahoo.com 


\section{INTRODUCERE}

În timpul erupţiei molarilor de 6 ani şi a incisivilor, ocluzia copilului se sprijină la nivelul grupurilor de dinți temporari alcătuite din canini, molarii I şi II. Datorită acestui fapt, aceste zone se numesc zone de sprijin ale ocluziei sau zonele Korkhaus (1-4).

Pe lângă rolul de a stabiliza relația verticală de ocluzie, zona Korkhaus mai are ca scop păstrarea spațiului necesar pentru erupția dinților succesionali (canini şi premolari). Atunci când integritatea zonei de sprijin nu este păstrată, din cauza nerezolvării corecte a proceselor carioase aproximale sau a extracțiilor precoce fără aplicarea unor menținătoare de spațiu, molarul de şase ani va avea posibilitatea de a se mezializa, micşorând astfel spaţiul de pe arcadă necesar erupției dinților succesionali. Astfel, va apărea o lipsă de spațiu pentru dintele care se va permuta ultimul în acea zonă (în general, caninul superior şi premolarul 2 inferior) (5-8).

Pierderea prematură a dinţilor din zona Korkhaus va avea repercusiuni asupra dinților succesionali ai acestei zone, frecvent apărând în dentiția permanentă incongruența dentoalveolară cu înghesuire $(9,10)$.

\section{SCOP}

Scopul studiului a fost evaluarea integrității dintilor temporari care alcătuiesc zona Korkhaus la un lot de pacienți cu vârsta cuprinsă între 6 şi 9 ani (72108 luni, varsta medie 88,43 luni), care au beneficiat de tratament stomatologic în cadrul Clinicii de Pedodonție a Facultății de Medicină Dentară UMF „Carol Davila“, Bucureşti.

\section{MATERIAL ŞI METODĂ}

Studiul retrospectiv observațional descriptiv a fost efectuat pe un lot care a curprins 140 de pacienți (70 fete şi 70 băieți) care au fost consultați şi trataţi în Clinica de Pedodonție din cadrul Facultății de Medicină Dentară UMF „Carol Davila“, Bucureşti.

Criteriile de încludere ale pacienților în lotul de studiu au fost:

- Pacienți cu vârsta cuprinsă între 7 şi 9 ani;

- Statusul pacienților a căror fişă era corectă şi completă.
Metoda de lucru a constat în analiza fişelor de observație clinică şi extragerea din acestea a datelor necesare studiului: date personale (nume, prenume, vârstă, sex); starea dinţilor care alcătuiesc zona Korkhaus: integri, cariați, obturați, pierduți precoce din cauza proceselor carioase sau pierduți prin rizaliză fiziologică. S-au calculat şi indicii de experiență carioasă pentru dentiția temporară şi cea permanentă: dmft/DMFT şi dmfs/DMFS.

Datele au fost prelucrate statistic utilizând programele Microsoft Excel 2010 si SPSS 12.0. Pentru compararea datelor obținute, s-au folosit testele ANOVA unifactorială şi Independent sample t-test. Nivelul de semnificație a fost fixat la $p=0,05$.

\section{REZULTATE}

1. Lotul examinat a fost format din 140 de copii (70 de băieți şi 70 de fete), cu vârste cuprinse între 6 şi 9 ani. Distribuția lotului de studiu în funcție de sex este prezentată în Fig. 1.

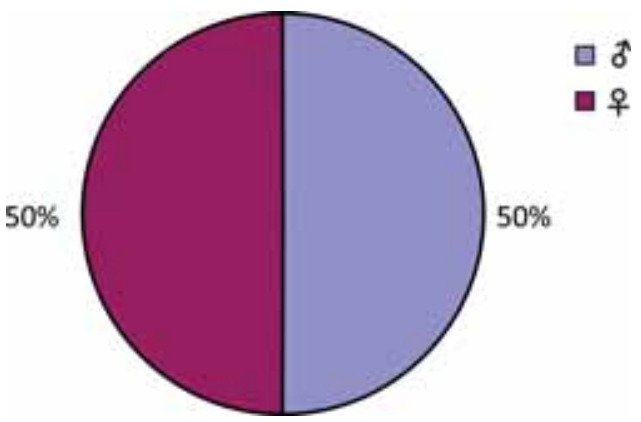

FIGURA 1. Distribuția pe sexe a copiilor examinați

În Tabelul 1 se observă distribuția în funcție de vârstă şi sex a pacienților cuprinşi în studiul prezent.

TABELUL 1. Distribuția în funcție de vârstă şi sex a lotului de studiu

\begin{tabular}{|c|c|c|c|c|c|c|c|c|}
\hline \multirow{2}{*}{$\begin{array}{l}\text { Vârsta } \\
\text { Sex } \\
\end{array}$} & \multicolumn{2}{|c|}{$\begin{array}{c}6 \text { ani } \\
\text { (72-83 luni) }\end{array}$} & \multicolumn{2}{|c|}{$\begin{array}{c}7 \text { ani } \\
\text { (84-95 luni) }\end{array}$} & \multicolumn{2}{|c|}{$\begin{array}{c}8 \text { ani } \\
\text { (96-107 luni) }\end{array}$} & \multicolumn{2}{|c|}{$\begin{array}{c}9 \text { ani } \\
\text { (108 luni) }\end{array}$} \\
\hline & $q$ & $\pi$ & q & 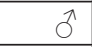 & $q$ & $\hat{0}$ & q & 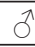 \\
\hline Nr. & 25 & 25 & 24 & 27 & 17 & 18 & 4 & 0 \\
\hline$\%$ & 17,86 & 17,86 & 17,14 & 19,29 & 12,14 & 12,86 & 2,86 & 0 \\
\hline
\end{tabular}

\section{Distribuția dinților integri din zona Korkhaus}

Din totalul dinților examinați (1.680), procentul celor integri a fost de $58,8 \%$, şi anume: 474 canini (28,21\%), $254 \mathrm{~m} 1(15,12 \%)$ şi $250 \mathrm{~m} 2$ (14,88\%). Analizând distribuția în funcție de sex şi arcada dentară s-au înregistrat la maxilar pentru fete 116 
canini (6,9\%), $61 \mathrm{~m} 1$ (3,63\%) şi $65 \mathrm{~m} 2$ (3,87\%), iar pentru băieți 119 canini (7,08\%), 73 m1 (4,35\%), $85 \mathrm{~m} 2$ (5,06\%), iar la mandibulă pentru fete 116 canini (6,9\%), $63 \mathrm{~m} 1$ (3,75\%), $53 \mathrm{~m} 2$ (3,15\%) şi pentru băieți 123 canini (7,32\%), $57 \mathrm{m1}$ (3,39\%) şi $57 \mathrm{~m} 2$ (3,39\%) (Fig. 2).

\section{Distribuția dinților cariați din zona Korkhaus}

Din totalul dinţilor examinați (1.680), procentul celor cariați a fost de $34,22 \%$ si anume: 56 canini (3,33\%), $252 \mathrm{~m} 1$ (15\%), $267 \mathrm{~m} 2$ (15,89\%). La maxilar numărul dinților cariați pentru fete a fost de 18 canini (1,07\%), $66 \mathrm{~m} 2(3,93 \%)$ şi $69 \mathrm{~m} 2(4,11 \%)$, iar pentru băieți 17 canini (1,01\%), $54 \mathrm{ml}$ (3,21\%), $47 \mathrm{~m} 2(2,8 \%)$. La mandibulă pentru fete 9 canini $(0,54 \%), 61 \mathrm{~m} 1(3,63 \%), 81 \mathrm{~m} 2$ (2,58\%) şi pentru băieți 12 canini $(0,72 \%), 71 \mathrm{~m} 1(4,23 \%)$ şi $70 \mathrm{~m} 2$ (4,17\%) (Fig. 3).

\section{Distribuția dinților obturați din zona Korkha-} us

Din totalul dinţilor examinați (1.680), procentul celor obturați a fost de 2,26 \% si anume: 0 canini (0\%), $18 \mathrm{~m} 1(1,07 \%), 20 \mathrm{~m} 2$ (1,19\%). La maxilar numărul dinților obturați pentru fete a fost de $3 \mathrm{ml}$ $(0,18 \%)$ şi $3 \mathrm{~m} 2(0,18 \%)$, iar pentru băieți $6 \mathrm{~m} 1$ $(0,36 \%)$ şi $2 \mathrm{~m} 2(0,12 \%)$, iar la mandibulă pentru fete $3 \mathrm{~m} 1(0,18 \%)$ şi $6 \mathrm{~m} 2(0,36 \%)$ şi pentru băieți $6 \mathrm{~m} 1(0,36 \%)$ şi $9 \mathrm{~m} 2$ (0,54\%) (Fig. 4).

\section{Distribuția dinților pierduți prin rizaliză} fiziologică din zona Korkhaus

Din totalul dinților examinați (1.680), cei pierduţi prin rizaliză fiziologică au reprezentat 2,32\% si anume: 11 canini $(0,66 \%), 23 \mathrm{~m} 1(1,38 \%), 8 \mathrm{~m} 2$ $(0,48 \%)$. La maxilar numărul de dinți pierduți prin rizaliză fiziologică pentru fete a fost de 2 canini $(0,12 \%), 7 \mathrm{~m} 1(0,42 \%)$ şi $2 \mathrm{~m} 2(0,12 \%)$, iar pentru băieți 1 canini $(0,06 \%), 6 \mathrm{~m} 1 \quad(0,36 \%), 1 \mathrm{~m} 2$ $(0,06 \%)$, iar la mandibulă pentru fete 6 canini (0,36\%), $8 \mathrm{~m} 1$ (0,48\%), $0 \mathrm{~m} 2$ (0\%) şi pentru băieți 2 canini $(0,12 \%), 2 \mathrm{~m} 1(0,12 \%)$ şi $5 \mathrm{~m} 2(0,3 \%)$ (Fig. 5).

\section{Distribuția dinților pierduți precoce prin carie din zona Korkhaus}

Din totalul dinţilor examinați (1.680), cei pierduţi precoce prin carie reprezintă $2,38 \%$ si anume: 19 canini (1,14\%), $13 \mathrm{~m} 1$ (0,78\%), $8 \mathrm{~m} 2$ (0,48\%). La maxilar s-a calculat un număr de dinți pierduți precoce prin carie pentru fete 4 canini $(0,24 \%), 3$ m2 $(0,18 \%)$ şi $1 \mathrm{~m} 2(0,06 \%)$, iar pentru băieți 3 canini $(0,18 \%), 1 \mathrm{~m} 1(0,06 \%), 5 \mathrm{~m} 2(0,3 \%)$. La mandibulă pentru fete 9 canini $(0,54 \%), 5 \mathrm{ml}$

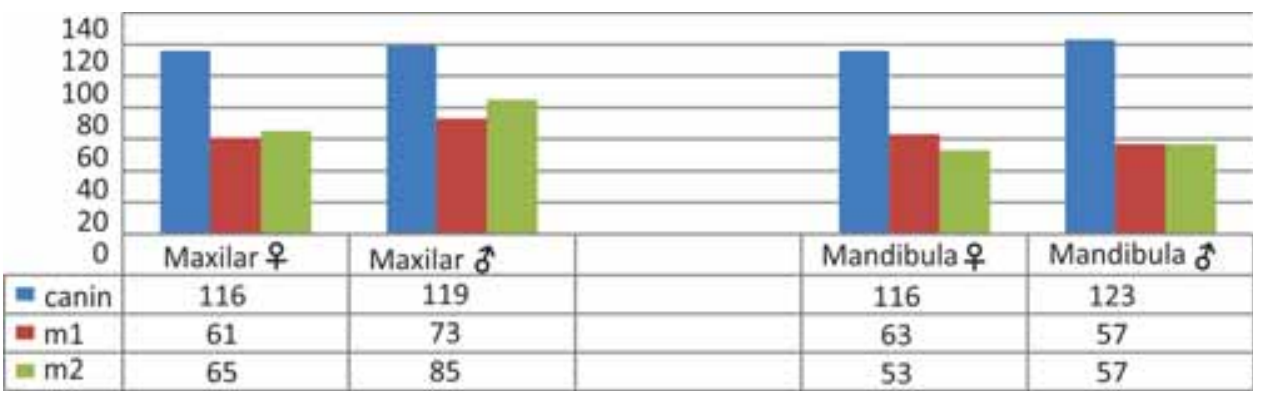

FIGURA 2. Distribuția dinților integri examinați în funcție de arcada afectată şi de sex

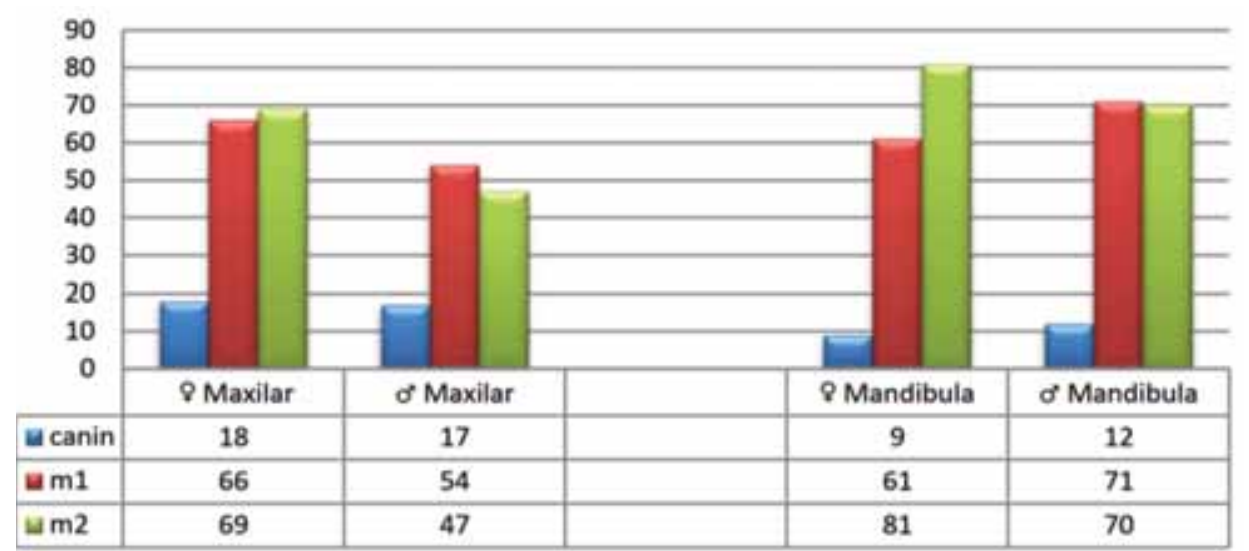

FIGURA 3. Distribuția dinților cariați la maxilar şi mandibulă în funcție de sex 


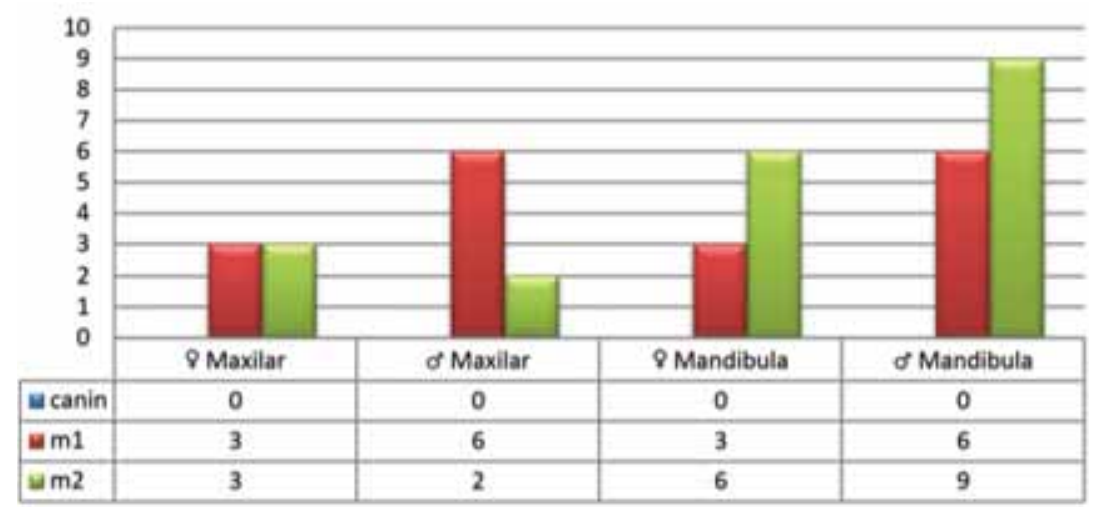

FIGURA 4. Distribuția dinților obturați la maxilar şi mandibulă în funcție de sex

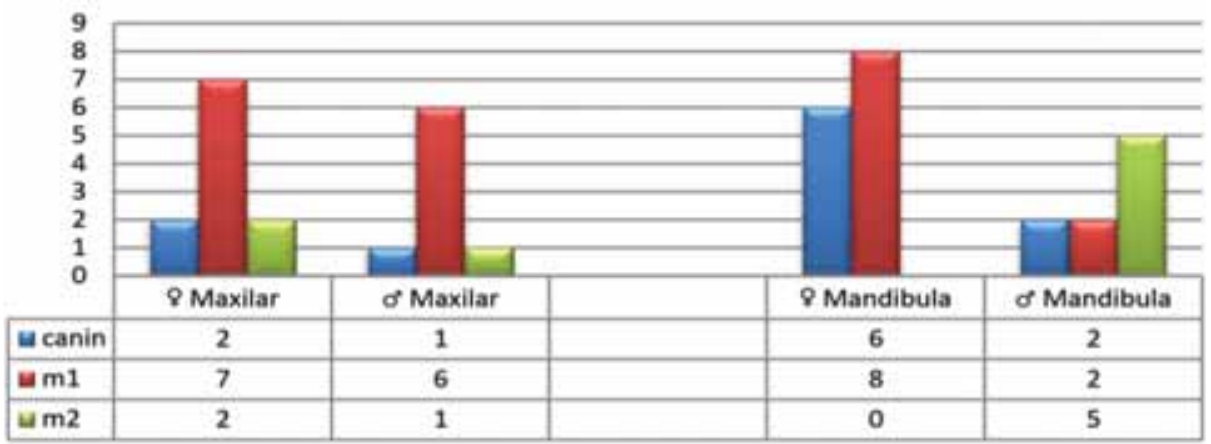

FIGURA 5. Distribuția dinților pierduți prin rizaliză fiziologică la maxilar şi mandibulă în funcție de sex

$(0,3 \%), 0 \mathrm{~m} 2(0 \%)$ şi pentru băieți 3 canini $(0,18 \%)$, $4 \mathrm{~m} 1(0,24 \%)$ şi $2 \mathrm{~m} 2$ (0,12\%) (Fig. 6).

\section{Indicii experienței carioase pentru dentiția temporară}

S-au calculat indicii experienței carioase pentru dentiţia temporară pentru întregul lot şi separat în funcție de sex.

Valoarea indicelul dmft pentru întregul lot a fost de $5,13 \pm 3,81$. La băieți indicele dmft a avut o valoare mai mare decât la fete, şi anume 5,28 şi respectiv 4,98, diferența nefiind semnificativă statistic $(\mathrm{p}>0,05$; Tabelul 2)
TABELUL 2. Valorile medii ale indicelui dmft pentru întregul lot şi pentru fiecare sex

\begin{tabular}{|l|c|c|}
\hline & Valoare & Deviația standard \\
\hline$q$ & 5,28 & $\pm 3,72$ \\
\hline$\hat{0}$ & 4,98 & $\pm 3,92$ \\
\hline Întregul lot & 5,13 & $\pm 3,81,74$ \\
\hline
\end{tabular}

In Tabelul 3 sunt prezentate valorile medii ale indicelui dmfs şi deviațiile standard ale acestora pentru întregul lot şi separat pentru fiecare sex la fete, respectiv băieți. Nu au existat diferențe semnificative statistic între cele două sexe privind valoarea indicelui dmfs $(\mathrm{p}>0,05)$.

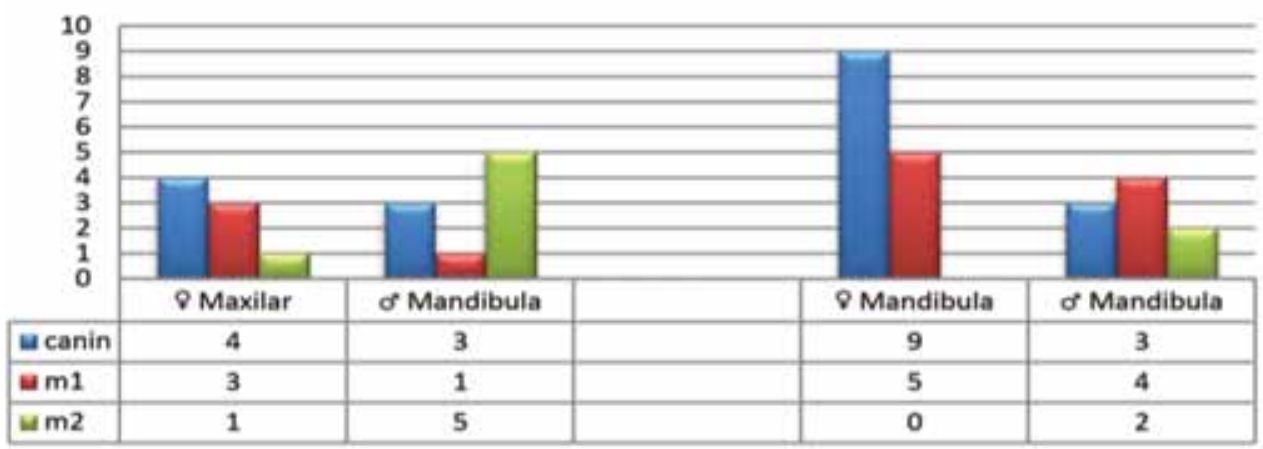

FIGURA 6. Distribuția dinților pierduți precoce prin carie la maxilar şi mandibulă în funcție de sex 
TABELUL 3. Valorile medii ale indicelui dmfs pentru întregul lot şi pentru fiecare sex

\begin{tabular}{|l|c|c|}
\hline & Valoare & Deviația standard \\
\hline$q$ & 11,62 & $\pm 10,64$ \\
\hline \multirow{\delta}{}{} & 11,47 & $\pm 12,82$ \\
\hline Întregul lot & 11,55 & $\pm 11,74$ \\
\hline
\end{tabular}

\section{Indicii experienței carioase pentru dentiția permanentă}

În Tabelul 4 şi 5 sunt prezentate valorile medii ale indicilor DMFT şi DMFS pentru întregul lot şi separat pentru ambele sexe. La dentitia permanentă, valoarea ambilor indici a fost semnificativ statistic mai mare la fete comparativ cu băieții: $p=0,0167$ pentru DMFT şi $p=0,023$ pentru DMFS.

TABELUL 4. Valorile medii ale indicelui DMFT pentru întregul lot şi pentru fiecare sex

\begin{tabular}{|l|c|c|}
\hline & Valoare & Deviația standard \\
\hline$q$ & 0,90 & $\pm 1,49$ \\
\hline \multirow{2}{*}{} & 0,67 & $\pm 1,13$ \\
\hline Întregul lot & 0,78 & $\pm 1,32$ \\
\hline
\end{tabular}

TABELUL 5. Valorile medii ale indicelui DMFS pentru întregul lot şi pentru fiecare sex

\begin{tabular}{|l|c|c|}
\hline & Valoarea & Deviația standard \\
\hline+ & 1,07 & $\pm 1,76$ \\
\hline$\hat{O}$ & 0,74 & $\pm 1,29$ \\
\hline Întregul lot & 0,90 & $\pm 1,54$ \\
\hline
\end{tabular}

\section{DISCUŢII}

Zona de sprijin Korkhaus are un rol important atât în stabilizarea relației verticale de ocluzie, cât şi în păstrarea spațiului necesar pentru erupția dinților succesionali (canini şi premolari). Atunci când integritatea zonei de sprijin nu este păstrată, din cauza nerezolvării corecte a proceselor carioase aproximale sau a extracțiilor precoce fără aplicarea unor menținătoare de spațiu, molarul de şase ani se va mezializa, micşorând astfel spaţiul de pe arcadă necesar erupției dinților succesionali. Dat fiind gradul mare de afectare prin carie a zonei Korkhaus, studiul de față a avut drept scop evaluarea integrității dinţilor temporari care alcătuiesc zona de sprijin Korkhaus la un lot de pacienți cu vârsta cuprinsă între 6 şi 9 ani.

S-a obținut un număr de 12 pacienți care prezintă toate cele 4 zone Korkhaus integre, număr ce reprezintă $8,57 \%$ din total, cei mai mulți fiind copii cu vârsta de 7 ani. Cei mai mulţi dinţi integri au fost caninii, în număr de 474, reprezentând $28,21 \%$ din totalul dinților examinați şi $82,43 \%$ din totalul dinților integri, procent mult mai mare decât cel obținut de catre A.C. Iliescu în 2012, cu un procent de $52,5 \%$ din totalul dinților integri (11-14).

Dinții cariați reprezintă $34,22 \%$, şi anume: 56 canini (3,33\%/9,74\%), $252 \mathrm{ml}$ (15\%/43,83\%), 267 $\mathrm{m} 2(15,89 \% / 46,43 \%)$ - al doilea fiind procentul din totalul dinților cariați.

Faraz A. Farooqi şi colab. din Arabia Saudită au calculat un procent de $78 \%$ de dinți afectați prin carie, o valoare dublă față de cea găsită în studiul de față (15).

Cei mai mulți dinți cariați au fost $m 2$ în număr de 267, cu prevalența cea mai mare la baieții de 6 ani cu un număr de 155. Mandibula este cea mai afectată, cu prevalența crescută pentru fete, unde s-a găsit numărul cel mai mare de dinți afectați ca fiind $\mathrm{m} 2$ cu o valoare de 81 la sexul feminin. Comparativ dreapta-stânga, cea mai afectată este partea stângă unde tot $\mathrm{m} 2$ este cel mai aefectat cu un număr de $139 \mathrm{~m} 2$, cu maxim pentru fete, unde s-a gasit un număr de $76 \mathrm{~m} 2$. Cel mai afectat cadran este cadranul 4 , unde tot $\mathrm{m} 2$ este cel mai afectat şi tot sexul feminin are prevalența mai mare cu un număr de 43 m2. Într-un studiu efectuat în India de către Vinay Kumar Bhardwaj s-a găsit că, spre deosebire de studiul prezent, sexul feminin este mult mai afectat de carie decât cel masculin (79,3\%) (16).

Tot în acest studiu au găsit o afectare mai mare a m1 78,69\% şi o afectare mai mare a mandibulei față de maxilar, $51,3 \%$ vs. 46,56\%. Însă autorul nu a găsit în studiul lui o diferență relevantă în funcție de vârstă şi sex asupra acestora (16).

Dinții obturați reprezintă $2,26 \%$, ceea ce reprezintă o situație alarmantă raportându-ne la numărul dinților afectați de carie. A.C. Iliescu a găsit un procent de 7\% dinți obturați la un lot asemănător, procent care, deşi mai mare, nu este deloc liniştitor (11).

Dinții pierduți precoce prin carie reprezintă 2,38\%. Cei mai mulți sunt canini în număr de 19 (1,14\%), urmat de $13 \mathrm{~m} 1$ (0,78\%), $8 \mathrm{~m} 2$ (0,48\%). A.C.Iliescu şi colab. găsesc în 2012 procente de 5\% pentru canin, $12 \% \mathrm{~m} 1$ si $8,5 \%$ pentru $\mathrm{m} 2$. Prin comparație se observă afectarea diferită ca frecvență, în studiul din 2012 cel mai afectat fiind $\mathrm{m} 1$, precum şi diferența mare a procentului maxim al afectării (11).

Într-un studiu publicat în 2014 de către Anne Marie Rauten şi colab. se observă o frecvență mai 
mare pentru $\mathrm{m} 2 \mathrm{cu}$ un număr de 32 , reprezentând 4,49\% din totalul dinților examinați la nivelul zonei Korkhaus, date ce sunt similare cu rezultatele obținute de către Ana Petcu şi colab. şi publicate în 2009; ceea ce arată, pe lângă frecvența mai mare de afectare a unui dinte diferit, şi un procent mai semnificativ faţă de studiul prezentat $(17,18)$.

Dinții pierduți prin rizaliză fiziologică au reprezentat un procent de $2,32 \%$, caninul fiind dintele cel mai afectat $(0,66 \%)$.

În ceea ce priveşte valorile indicilor de experiență carioasă, scorul dmft de 4,98 la băieți și de 5,28 la fete este mai mare față de cel obţinut de A.C. Iliescu şi colab. în 2012 de 4,03 băieți şi 4,08 fete $(17,11)$.

Cel mai mare scor dmft s-a obținut pentru fetele cu vârsta de 6 ani şi anume 6,84, scor apropiat de cel obținut de către Saeeda Abdullah în Pakistan în 2005 pentru acelaşi lot de 7,45 (19).

Scorul DMFT de 0,78 este mai mic decât cel obținut de Dănilă I. în 2003-2004 de 2,35 sau Zmărăndache D.D.D. în 2011 de 2,8 şi apropiat de cel obținut de Levine R.S. et al 2007 de 0,82 sau de Andreea Cristina Iliescu în 2012 de 0,98, însă este mai mare decât cel obținut de către Baginska J. în 2013 în Polonia de 0,33 (11,17,20).

Cel mai mare DMFT s-a obținut pentru vârsta de 8 ani cu un scor de 1,4; mai mare decât cel obținut de către Bahinska J. în 2013 Polonia de 0,5 pentru aceeaşi grupă de vârstă [20]. Scorul de dmfs este de 11,55 , cu un maxim obținut pentru vârsta de 6 ani de

\section{BIBLIOGRAFIE}

1. Graber T.M., Vanarsdall R.L., Vig K.W. Orthodontics Current Principles and Techniques - 4th ed., St Louis, Elsevier Mosby, 2005:3-15.

2. Proffit W.R., Fields W.H., Sarver D.M. Contemporary Orthodontics - 4th edition, Mosby, 2006, 3-25.

3. Macena M.C., Tornisiello Katz C.R., Heimer M.V., de Oliveira E., Silva J.F., Costa L.B. Space changes after premature loss of deciduous molars among Brazilian children, Am J Orthod Dentofacial Orthop, 2011, 140, 771-778.

4. Leheni Vernescu Victoria. Anomalii dento-alveolare. Forme clinice - Tratament, Ed. Medicală Bucureşti, 1974, 46-85.

5. Popovich F., Thompson G.W. Space Maintenance. In, Preventive dental services. 2nd ed., D.W. Lewis Ed., Ottawa, Canada: Minister of Supply Services, 1988, 192-196.

6. American Academy on Pediatric Dentistry, Clinical affairs Committee-Developing Dentition Subcommittee. - Guideline on management of the developing dentition and occlusion in pediatric dentistry, Pediatr Dent, 2008-2009, 30, 7, 184-195.

7. Lin Y.T., Lin W.H., Lin Y.T.J. Twelve-month space changes after premature loss of a primary maxillary first molar, Int $\mathrm{J}$ Paediatr Dent, 2011, 21, 161-166.
14,62. Scorul DMFS este de 0,90 cu valori de 1,07 pentru fete şi 0,74 pentru băieți.

\section{CONCLUZII}

Studiul de față demonstrează gradul mare de afectare a zonei Korkhaus la copiii care au frecventat serviciul de specialitate. Dat fiind faptul că studiul a fost realizat la copii trataţi în serviciu de specialitate şi nu pe copii provenind din populația generală, era de aşteptat ca afectarea să fie mai mare.

Totodată, studiul demonstrează faptul că majoritatea părinţilor îşi aduc copilul la medicul stomato$\log$ numai în momentul în care prezintă dureri cauzate de cariile dentare, eventual carii complicate care au simptomatologie importantă. Acest lucru reduce foarte mult posibilitatea medicului de a realiza o profilaxie adecvată într-un serviciu de specialitate, de cele mai multe ori serviciile adresânduse tratamentului cariei şi complicațiilor ei, fiind prea târziu pentru profilaxia prin sigilare. Pentru reducerea afectării, este foarte importantă realizarea unor programe de sănătate orală în şcoli şi grădinițe, care să se adreseze celor două grupuri țintă: părinții şi copiii.

Notă: Autorii au contribuit în mod egal la prezentul articol, de aceea toți sunt considerați autori principali.

Conflict of interest: none declared Financial support: none declared

8. Lin Y.T., Lin W.H., Lin Y.T.J. Immediate and six-month space changes after premature loss of a primary maxillary first molar, J Am Dent Assoc, 2007, 138, 362-368.

9. Tunison W., Flores-Mir C., Elbadrawy H., Nassar U., EIBialy T. Dental arch space changes following premature loss of primary first molars: A systematic review, Pediatric Dentistry, 2008, 30, 297-302.

10. Park K., Jung D.W., Kim J.Y. Three-dimensional space changes after premature loss of a maxillary primary first molar, International Journal of Paediatric Dentistry, 2009, 19, 383-9.

11. Iliescu A.C., Luca R. Dental status of the teeth that form the Korkhaus zone and that of the six year mollars in patients aged 72-149 months. Revista Română de Stomatologie, Vol. 1, LX, nr. 1, 2016, 16-20.

12. Holst D. Causes and prevention of dental caries: a perspective on cases and incidence. Oral Health Prev Dent, 2005, 3:9-14.

13. Beltran-Aguilar E.D., Barker L.K., Canto M.T., Dye B.A., Gooch B.F., Griffin S.O. et al. Surveillance for dental caries, dental sealants, tooth retention, edentulism, and enamel 
fluorosis - United States,1988-1994 and 1999-2002. In MMWR CDC Surveill Volume 54. Atlanta G.A. US Department of Health and Human Services, Centers for Disease Control and Prevention, 2005, 1-44.

14. Takeuchi M. Epidemiological study on dental caries in Japanese children before, during and after WWII. Int Dent $J$ 1961, 11:443-457.

15. Faraz A.F., Abdul K., Imran M. et al. Prevalence of dental caries in primary and permanent teeth and its relation with tooth brushing habits among schoolchildren in Eastern Saudi Arabia. Saudi Med K, Jun 2015, 36(6): 737-742. [Online]. Disponibil pe: https://www.ncbi.nlm.nih.gov/pmc/articles/ PMC4454910/

16. Bhardwai V.K. Dental caries prevalence in individual tooth in primary and permanent dentition among 6-12-year-old school children in Shimla, Himachal Pradesh. International Jurnal of Health\&Allied Sciences, Vol 3, no. 2, 2014, 125-128 [Online]. Disponibil pe: http://www.ijhas.in/article.asp?issn=2278344X;y ear=2014; volume=3;issue=2; spage=125; epage $=128$; aulast $=$ B hardwaj;type $=0$

17. Zmarandache D.D.D., Luca R., Chiş A.C., Farcaşiu C. Carious Activity in 12 Year-Old Children from Slatina, Romania. International Journal of Medical Dentistry, 2012, 1: 27-32.

18. Rauten A-M., Georgescu C.T., Surlin P. et al. Prevalence of premature loss of temporary teeth in the Korkhaus support area because of dental caries in patients with malocclusion. Analele Universităţii "Dunarea de jos" din Galaţi, Fascicula XVII, no. 2, 2014, 47-51.

19. Abdullah S., Qazi H.S., Maxood A. Dental caries status in 6-9 years old children. Pakistan Oral\&Dental Journal, Vol 28, No. 1, 107-111.

20. Bagińska J., Linczuk E. Dental caries profile among 6-8-year old children from Bialystok District, Poland. Prog Health Sci 2013, Vol 3, No2, Caries profile among children from Bialystok District. Vol. 3(2), 2013, 53-58. 